\title{
SODIUM CONTENT IN CHEESES: SUITABILITY TO THE VOLUNTARY AGREEMENT AND LABELING
}

\section{TEOR DE SÓDIO EM QUEIJOS: ADEQUAÇÃO AO ACORDO VOLUNTÁRIO E A ROTULAGEM}

\author{
Fábio Zacouteguy Ugalde ${ }^{1}$ ORCID - http://orcid.org/0000-0002-2626-1263 \\ Kauan Trindade Mello ${ }^{1}$ ORCID - http://orcid.org/0000-0002-9962-1338 \\ Graciela Salete Centenaro ${ }^{1}$ ORCID - http://orcid.org/0000-0003-0279-1689 \\ Valcenir Júnior Mendes Furlan ${ }^{1 *}$ ORCID - http://orcid.org/0000-0003-0457-0687 \\ ${ }^{1}$ Universidade Federal do Pampa, Itaqui, RS, Brasil. \\ *Autor para correspondência - juniorfurlan@yahoo.com.br
}

\begin{abstract}
This study was done to establish the sodium concentration in the cheeses marketed in the western border region of the Rio Grande do Sul. A total of 30 cheese samples (grated Parmesan, Mozzarella, Prato and Artisanal) were collected from different brands and lots. After analyzing them under atomic emission spectroscopy, in quadruplicate, the sodium levels were ascertained. From the quantification of the sodium content significant differences were noted among the lots of all the cheese brands assessed. The results clearly revealed that $44.4 \%$ of the companies had listed nutritional values on the labels that were noncompliant with the legislation. Besides, $77.8 \%$ of the brands failed to reduce the sodium concentration to the levels jointly decided upon by the Ministry of Health and Brazilian Association of Food Industries, which should have been achieved ideally towards the end of 2016. While the Artisanal cheeses did not register high concentrations of sodium, the formulation of the grated Parmesan cheese was characterized by its high sodium content $(2014.56 \mathrm{mg} / 100 \mathrm{~g})$, as well as by its steady rise in sodium concentration over the years. This is indicative of the inattentiveness of the industry towards the consumers, as stringent laws to standardize the quantity of added salt in cheeses preparations are nonexistent.
\end{abstract}

Key words: dairy products, flame photometry, nutrition labeling, salt.

\section{Resumo}

O objetivo deste trabalho foi determinar a concentração de sódio em queijos comercializados na região da fronteira oeste do Rio Grande do Sul. Foram coletadas 30 amostras de queijos (Parmesão ralado, Muçarela, Prato e Artesanal) de diferentes marcas e lotes, as quais foram analisadas em quadruplicata quanto ao conteúdo de sódio, empregando a espectroscopia de emissão atômica. A quantificação do teor de sódio permitiu constatar que houve diferença significativa entre os lotes de todas as marcas de queijos avaliadas. Os resultados indicaram que $44,4 \%$ das empresas estavam com os valores da rotulagem nutricional em desacordo com a legislação. Além disso, $77,8 \%$ das marcas não cumprem a meta para redução de sódio acordada entre o Ministério da Saúde e Associação Brasileira das Indústrias da Alimentação, a qual deveria ter sido alcançada até o final do ano de 2016. Em relação aos queijos Artesanais não foram registradas altas concentrações de sódio. O queijo Parmesão ralado destacou-se pelo elevado conteúdo de sódio em sua formulação (2014,56 $\mathrm{mg} / 100 \mathrm{~g}$ ) e também pelo aumento da adição deste mineral com o passar dos anos. Com isso, evidencia-se a negligência da indústria em relação aos consumidores, devido à ausência de leis para padronizar a adição de 
sal na preparação de queijos.

Palavras-chave: fotometria de chama; produtos lácteos; rotulagem nutricional; sal.

Received on: September 29, 2018

Accepted on: January 10, 2019

\section{Introduction}

Traditionally, Brazil ranks high among the principal milk producing countries. This very old practice, carried on for a long time, is today a major source of the Brazilian economy and also among its most vital agribusinesses $^{(1)}$. In 2015, the milk yield in Brazil was 35.0 billion liters ${ }^{(2)}$. From the data recorded in the Brazilian Association of Cheese Industries (ABIQ), it was evident that the Brazilian average cheese consumption per inhabitant was $5.1 \mathrm{~kg}$ in 2014 , and this level is projected to escalate on average up to $11.0 \mathrm{~kg}$ in $2030^{(3)}$.

During the cheese manufacturing process, the milk undergoes several changes, the main ones being coagulation, acidification, syneresis, molding and salting. Salting is a highly significant stage, as sodium chloride $(\mathrm{NaCl})$ plays vital roles in cheese production. These include microbial control, taste, regulation of biochemical and physicochemical processes, besides others. Some cheese varieties undergo a maturation process during which salting is highly influential. If this process is not performed well the microbial and enzymatic activities of the product may be affected and result in many types of cheese defects ${ }^{(4)}$.

Sodium consumption in small quantities is crucial for the proper functioning of an organism because of its role in controlling the intra- and extra-cellular fluids, as well as maintenance of blood pressure, and is thus an essential mineral for humans. However, when consumed in excess, sodium can induce chronic noncommunicable diseases (CNCD) such as arterial hypertension, cardio- and cerebrovascular diseases $^{(5)}$. In 2013, the percentage of individuals 18 years and above who reported a diagnosis of arterial hypertension in Brazil was 21.4\%, which translates to mean 31.3 million people $^{(6)}$.

As salt exhibits several technological advantages in food production, and along with the absence of stringent checks and control, many industries ultimately utilize an excess of this mineral. At present, the salt consumption at a national level is around 4,700 $\mathrm{mg}$ of sodium per day, compared to the prescribed World Health Organization (WHO) limit of a maximum of 2,000 mg/day ${ }^{(7)}$.

In light of this fact, the Ministry of Health signed an agreement in 2011 with the Brazilian Association of Food Industries (ABIA), providing for a gradual decrease in the sodium content in industrialized foods, in which a class of products is included at each step of the process. In November 2013, the V Commitment Term was signed for the categories of dairy products, ready meals (soups) and meat products, for which the ultimate time limit for adaptation was until the culmination of $2016^{(8)}$. In fact, since 2011, a remarkable 17 thousand tons of sodium in industrialized foodstuffs have already been removed from the sodium reduction plan and the aim is to achieve 28 thousand tons by $2020^{(9)}$.

Therefore, because cheese is regarded as a significant food category in the Brazilian diet and appreciating the risks the population faces as a result of excessive salt intake, the aim of this work was to establish the sodium content in the different varieties and brands of cheeses marketed in the 
western border region of the Rio Grande do Sul.

\section{Material and Methods}

The cheese samples were purchased from commercial establishments in the western border region of Rio Grande do Sul, Brazil. The samples were then identified, transported in thermal boxes and stored under temperatures of $-18^{\circ} \mathrm{C}$ until they were analyzed. Four types of cheeses (Grated Parmesan, Mozzarella, Prato and Artisanal) from three different leading brand names in the Brazilian market, were collected, to make a total of 12 brands (A, B, C, D, E, F, G, H, I, J, K, L). Three distinct lots (L1, L2 and L3) were evaluated from each brand with the exception of Artisanal cheese (Figure 1).

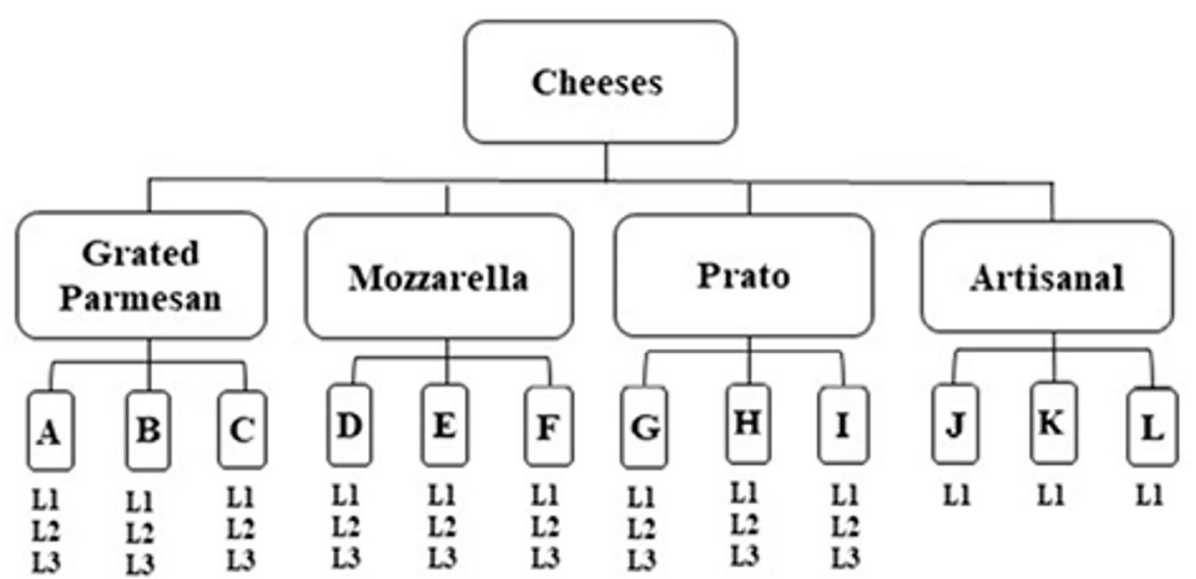

Figure 1. General scheme of sampling performed for analytical determinations.

Utilizing atomic emission spectroscopy, based on the Ministry of Agriculture, Livestock and Supply (MAPA) ${ }^{(10)}$ methodology, the sodium concentrations of the cheeses was ascertained. The methodology involved first carbonizing the cheese sample and, then incinerating it in the muffle furnace at $525{ }^{\circ} \mathrm{C}$ for 4 hours, to obtain the ashes. Later, the minerals were dissolved in nitric acid and this solution was filtered using a volumetric flask. Readings were taken in a flame photometer (Digimed - DM 62). The sodium contents thus obtained experimentally were assessed to observe their compliance with the goal established in the V Term of Commitment and were compared with the values listed on the product labels.

The results were submitted to the analysis of variance (ANOVA). Significant differences were noted through the performance of a comparison test between the means at the $5.0 \%$ level of significance. Prior to performing the ANOVA, the data were verified to check if they were normal (Kolmogorov-Smirnov test) and if their variances were identical (Cochran's Q test) ${ }^{(11)}$.

\section{Results and Discussion}

Table 1 lists the sodium concentration after analyzing each cheese brand from three different batches, in 
quadruplicate. The values reported on the labels by the manufacturers are also shown.

Table 1. Sodium content in the samples of the grated Parmesan, Mozzarella and Prato cheeses

\begin{tabular}{|c|c|c|c|c|c|}
\hline Product & Brand & Lot & $\begin{array}{l}{ }^{*} \text { Sodium by lot } \\
(\mathrm{mg} / \mathbf{1 0 0} \mathrm{g})\end{array}$ & $\begin{array}{c}\text { Average sodium } \\
\text { by brand } \\
\text { (mg/100 g) }\end{array}$ & $\begin{array}{l}\text { Sodium declared on } \\
\text { the label }(\mathrm{mg} / 100 \mathrm{~g})\end{array}$ \\
\hline \multirow{9}{*}{$\begin{array}{l}\text { Grated } \\
\text { Parmesan }\end{array}$} & \multirow{3}{*}{ A } & 1 & $2077.51 \pm 31.31^{\mathrm{a}}$ & \multirow{3}{*}{$2014.56 \pm 113.41$} & \multirow{3}{*}{1616.00} \\
\hline & & 2 & $1868.64 \pm 22.91^{b}$ & & \\
\hline & & 3 & $2097.53 \pm 52.98$ a & & \\
\hline & \multirow{3}{*}{$\mathrm{B}$} & 1 & $1865.06 \pm 64.36^{a}$ & \multirow{3}{*}{$1877.20 \pm 114.39$} & \multirow{3}{*}{1860.00} \\
\hline & & 2 & $1790.33 \pm 95.44^{a}$ & & \\
\hline & & 3 & $1976.20 \pm 106.78^{b}$ & & \\
\hline & \multirow{3}{*}{$\mathrm{C}$} & 1 & $1457.51 \pm 27.76^{\mathrm{a}}$ & \multirow{3}{*}{$1733.92 \pm 209.63$} & \multirow{3}{*}{1860.00} \\
\hline & & 2 & $1853.46 \pm 35.56^{b}$ & & \\
\hline & & 3 & $1890.78 \pm 28.31^{b}$ & & \\
\hline \multirow{9}{*}{ Mozzarela } & \multirow{3}{*}{$\mathrm{D}$} & 1 & $320.46 \pm 9.63 \mathrm{a}$ & \multirow{3}{*}{$247.12 \pm 55.42$} & \multirow{3}{*}{533.33} \\
\hline & & 2 & $200.24 \pm 6.98^{b}$ & & \\
\hline & & 3 & $220.66 \pm 9.29^{c}$ & & \\
\hline & \multirow{3}{*}{ E } & 1 & $640.87 \pm 57.34 \mathrm{a}$ & \multirow{3}{*}{$562.64 \pm 71.55$} & \multirow{3}{*}{533.33} \\
\hline & & 2 & $490.29 \pm 8.34^{b}$ & & \\
\hline & & 3 & $556.78 \pm 15.04^{b}$ & & \\
\hline & \multirow{3}{*}{$\mathrm{F}$} & 1 & $482.88 \pm 53.24^{a}$ & \multirow{3}{*}{$472.67 \pm 52.50$} & \multirow{3}{*}{383.33} \\
\hline & & 2 & $494.10 \pm 36.60^{b}$ & & \\
\hline & & 3 & $441.04 \pm 62.02^{\mathrm{c}}$ & & \\
\hline \multirow{9}{*}{ Prato } & \multirow{3}{*}{ G } & 1 & $298.27 \pm 9.00^{\mathrm{a}}$ & \multirow{3}{*}{$396.30 \pm 73.14$} & \multirow{3}{*}{500.00} \\
\hline & & 2 & $442.45 \pm 8.14^{b}$ & & \\
\hline & & 3 & $448.18 \pm 15.13^{\circ}$ & & \\
\hline & \multirow{3}{*}{$\mathrm{H}$} & 1 & $851.51 \pm 19.29 a$ & \multirow{3}{*}{$653.01 \pm 147.82$} & \multirow{3}{*}{663.33} \\
\hline & & 2 & $548.83 \pm 19.27^{b}$ & & \\
\hline & & 3 & $558.68 \pm 22.42^{b}$ & & \\
\hline & \multirow{3}{*}{ I } & 1 & $425.91 \pm 17.58$ a & \multirow{3}{*}{$484.89 \pm 74.67$} & \multirow{3}{*}{533.33} \\
\hline & & 2 & $581.35 \pm 20.13^{\circ}$ & & \\
\hline & & 3 & $447.41 \pm 28.09 \mathrm{a}$ & & \\
\hline
\end{tabular}

*Mean values \pm standard deviation ( 4 replicates); averages followed by the same lower case letters in the column do not differ at the $5 \%$ level of significance by the Tukey test.

The results of Table 1 enabled the conclusion to be drawn that a significant difference $(\mathrm{p}<0.05)$ was evident between at least two lots of each cheese brand assessed. The differences in the sodium content among the various lots of brands A, B, C, D, E, F, G, H and I were as high as $10.9 ; 9.4 ; 22.9 ; 37.5$; $23.5 ; 10.7 ; 33.4 ; 35.5 ; 26.7 \%$, respectively. This clearly reveals that the companies showed no interest in standardizing the quantities of the ingredients added during the manufacturing process of a product. It is well known that standardization is the foundation for continuous improvements to be made. When adequate standards are implemented, they reduce the production errors, thus facilitating the production system to be continuously improved ${ }^{(12)}$. 
Among the nine brands assessed, four (44.4\%) were found to have a higher sodium content than the value declared by the label (Table 1). According to the RDC $360 / 2003$, variability of up to $20.0 \%$ is permissible with respect to the nutrient values listed on the label ${ }^{(13)}$. In this paper, the data analyzed was compared with the declared values and, from Figure 2, it is evident that the A, D, F and G brands had values higher than that of the maximum tolerance level (20.0\%), allowed by Brazilian law. Hence, it must be noted that these companies are marketing their products in an unfitting manner.

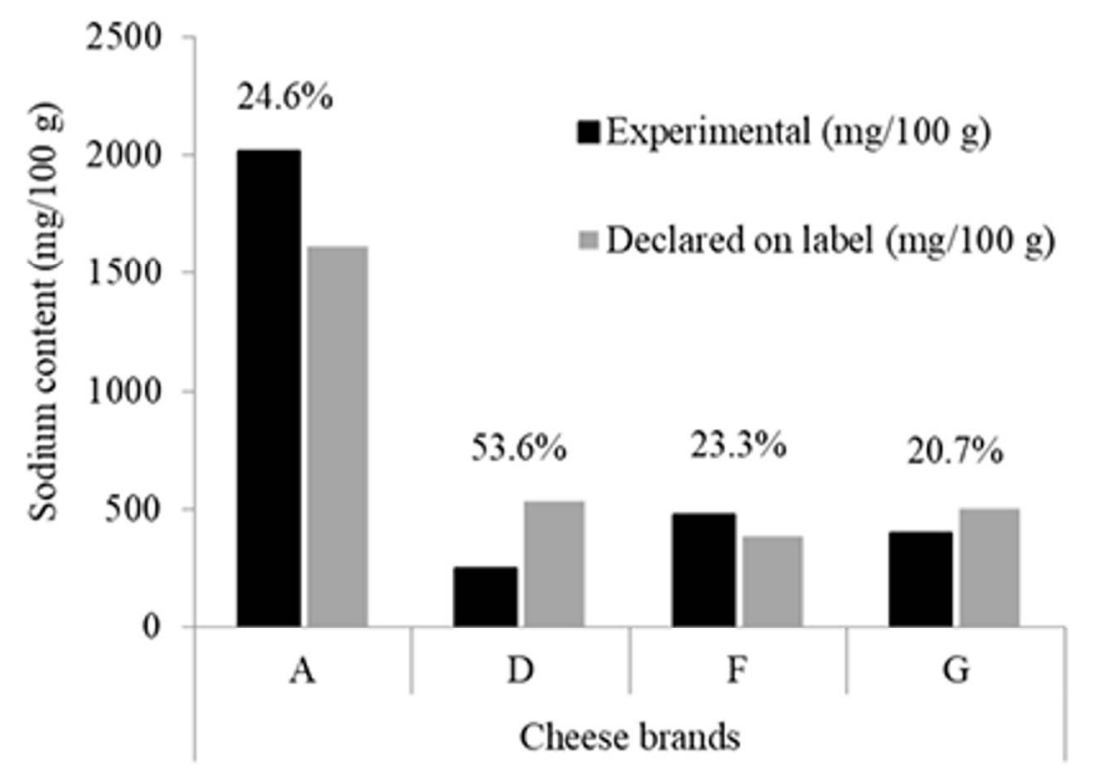

Figure 2. Differences in the sodium content of the analyzed brands compared to the values indicated on the label.

Other studies too had reported this violation of the provisions of the RDC 360/2003 of the National Health Surveillance Agency (ANVISA) and the rights guaranteed by the food safety, nutritional and consumer protection laws. In fact, Karam et al., ${ }^{(14)}$ after comparing the information declared on the labels of seven cream cheese brands post laboratory analyses reported that $20.4 \%$ of the nutrients showed variabilities in the values declared on the labels, which were higher than those permissible by the RDC 360/2003. According to Silva and Ferreira ${ }^{(15)}, 92.0 \%$ of the cheese brands analyzed showed nutritional labeling noncompliant with the current legislation. These authors also noted discrepancies in the results for several nutrients, particularly sodium for example, which showed variations of up to $127.0 \%$ when the data analyzed were compared with the values stated on the label.

The Federal Law No. 6437 of August 1977 states that a product can incur suspension of its sale and/or manufacture only as the sixth designated penalty rule, after warning, fine, seizure, destruction and prohibition of the product ${ }^{(16)}$. However, the legislation in Brazil in terms of compliance with nutritional labeling continues to be disappointing, because an academic survey performed from 1987 to 2004 revealed a high degree of noncompliance with legislation ${ }^{(17)}$. From their study it was evident that Câmara et al., ${ }^{(17)}$ found that the norms and laws set for proper product labeling in Brazil are good; however, it is essential to transform the intention into action. This means that the implementation of the legislation needs to be satisfactorily inspected. The rights of the consumer to select safe and healthy food and reliable labeled information must be ensured both in the legal aspect, as well as through uninterrupted and regular surveillance. Santos ${ }^{(18)}$ reported that nutritional and food education are linked to information output which can enable the consumers to decide and choose, 
providing them the right to select healthier foods. Naturally, as the consumption of processed and industrialized foods is escalating, accurate labels are crucial in the choice of a healthier food, which is one important reason for the information declared on the labels to be true ${ }^{(19)}$.

Other brands, despite being compliant with the ANVISA permitted limits in terms of the nutrient values listed on the label, the degree of tolerance to noncompliance is extremely high $(20.0 \%)$; this violates the consumer defense code which declares that the basic rights of the consumer are to have "access to adequate and clear information about different products and services, with a correct quantity specification" ${ }^{\prime 20}$. Such tolerance to noncompliance indicates that the consumers are denied accurate information regarding the quantity of nutrients in the various foods.

For the years 2012 and 2014, ANVISA registered, respectively, average sodium levels of 766 and $1080 \mathrm{mg} / 100$ $\mathrm{g}$ in the grated Parmesan cheeses, 594 and $573 \mathrm{mg} / 100 \mathrm{~g}$ in the Mozzarella cheeses, and 657 and $527 \mathrm{mg} / 100$ $\mathrm{g}$ in the Prato cheeses (Figure 3). In the present study, all three Parmesan brands revealed sodium levels higher than the values prescribed by ANVISA, with brand A (2014.56 mg $100 \mathrm{~g})$ being 1.8 times above $(86.5 \%)$ the average $(1080 \mathrm{mg} / 100 \mathrm{~g})$ according to research done in $2014^{(21)}$. This indicates that the processing industries producing grated Parmesan cheese are not committed to adhere to the sodium reduction targets proposed for dairy products, because the contrary was evident, implying a significant rise, over the years, in the sodium concentration of this type of cheese.

Usually, the drier and more mature cheeses contain higher salt levels because of the lower moisture content in their composition. However, although a lower sodium content in the Parmesan cheese was anticipated from the established targets, it was not so. Some authors indicated that the high salt content is also useful in concealing some undesirable flavors, like "corral taste" and also help improve the flavor of bitter, acidic or rancid cheeses ${ }^{(22)}$, caused by the poor quality of the milk used ${ }^{(23)}$.

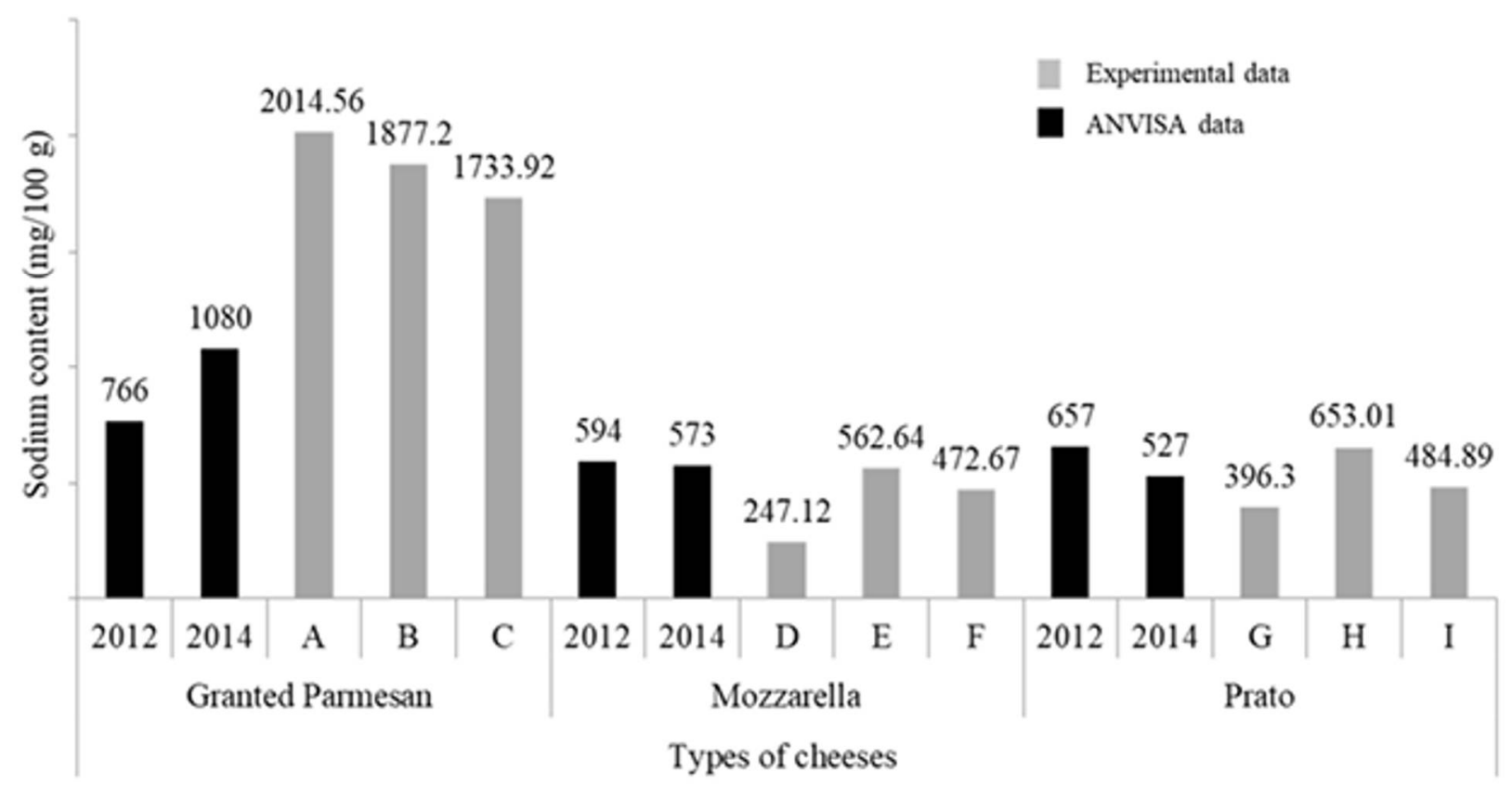

Figure 3. Sodium content analyzed in different cheese brands compared with ANVISA data.

The objective of the November 2013 agreement signed between the ABIA and the Ministry of Health was to ensure the gradual and spontaneous decrease in the sodium concentration in various foods by the industry. However, only one target was proposed for the cheese category, viz., that for Mozzarella cheese, the maximum permissible sodium limit should be $512 \mathrm{mg} / 100 \mathrm{~g}$ until 2016. The other cheeses have not yet been assigned targets; the only industrial initiative in connection with the Ministry of 
Health was to adopt, as a norm, a 50\% decrease in the sodium concentrations until the end of the first four years of the agreement ${ }^{(8)}$, because dairy products form the third most popular food category that imparts the most in terms of the sodium consumed by the population ${ }^{(24)}$.

From Figure 3, it is evident that the Mozzarella and Prato cheese producers have reduced the percentage of sodium in their product formulations since the time the agreement was signed. However, the stipulated target of $512 \mathrm{mg} / 100 \mathrm{~g}$ of sodium for Mozzarella and the $50.0 \%$ drop in the sodium concentration for the other cheeses, according to the signed agreement, were not met by the Mozzarella and Prato cheese brands, respectively, apart from the D and F brands.

However, large disparities have been recorded in the mean values of the sodium levels quantified among the different brands of the same product. The difference between the D and E brands of the Mozzarella cheese and the $\mathrm{G}$ and $\mathrm{H}$ brands of the Prato cheese reached up to $56.0 \%$ and $39.3 \%$, respectively. An even higher discrepancy was noted when different lots of the same cheese were compared; the difference between the D brand of lot 2 and $\mathrm{E}$ brand of lot 1 of the Mozzarella cheese went up to $68.7 \%$; the Prato cheese showed $64.9 \%$ discrepancy between the $\mathrm{G}$ brand of lot 1 and $\mathrm{H}$ brand of lot 1 (Table 1). This indicates that some companies have been able to significantly decrease the quantity of sodium added during the cheese preparation without affecting the qualities of the products and continuing to maintain good acceptance by the consumers.

Silva and Ferreira ${ }^{(15)}$, in their paper, reported that among all the cheese types analyzed, the sodium content was higher than all the other nutrients. In another study by Dickel et al., ${ }^{(25)}$ a high degree of variation was noted in the sodium concentrations of the Mozzarella cheese. These results further buttress the evidence that quality control had failed during the manufacture of these products. This indicates that regular and effective inspections must be conducted by competent agencies to control the addition of ingredients in the food products. These variations in the sodium concentrations among the cheese brands can be explained by the variations in the composition of the raw materials and ingredients used by the manufacturers, as well as by the differences in the processing procedures employed for these products ${ }^{(19)}$. Apart from this, the current lack of legislation and the establishment of the specific permissible minimum and maximum quantities of sodium have resulted in the producers' failure to employ any standardization in the amount of added sodium in the manufacturing process.

The escalating demands by society for reliable product-related information necessitates greater effort from the government and productive sector to implement effectively food labeling ${ }^{(26)}$. Therefore, this variation observed in the sodium content among the cheese brands makes it evident that consumers need to be attentive to food labels to make suitable selection of products.

Table 2 confirms that during the elaboration of the Artisanal cheeses marketed in this region, the sodium concentration was not in excess, even though these were produced informally and lacked a specific standard of processing when compared to the large dairy industries. 
Table 2. Sodium content in the Artisanal cheeses marketed in the western border of the Rio Grande do Sul

\begin{tabular}{ccccc}
\hline Product & Brand & Lot & $\begin{array}{c}\text { * Sodium } \\
(\mathbf{m g} / \mathbf{1 0 0} \mathbf{g})\end{array}$ & $\begin{array}{c}\text { Sodium declared on the label } \\
(\mathbf{m g} / \mathbf{1 0 0} \mathbf{g})\end{array}$ \\
\hline & $\mathrm{J}$ & 1 & $408.24 \pm 7.59$ & \\
Artisanal & $\mathrm{K}$ & 1 & $128.00 \pm 2.39$ & Not declared \\
& $\mathrm{L}$ & 1 & $390.99 \pm 5.94$ & \\
\hline
\end{tabular}

*Mean values \pm standard deviation (4 replicates)

From the research done by Lima et al., ${ }^{(27)}$, the Artisanal cheeses produced in the state of Pará showed high levels of added sodium; this is indicative of the absence of standardization in the manufacturing process of the cheeses produced under informal conditions, with variations in the salt concentrations, from small to high quantities.

According to Sebrae ${ }^{(28)}$ Artisanal cheeses are those that utilize traditional techniques, in a rudimentary fashion, in disagree with of the current legislation, lacking stringent quality control standards, and most often being marketed informally. This type of informal production frequently lacks the applicaation of sound agricultural and manufacturing practices and employs poor quality raw materials. Generally, the manufaturing processes are conducted under unsuitable and often unhygienic sanitary conditions, compromising the physicochemical and particularly, the microbiological quality of the cheese.

Although the Artisanal cheeses sold in the region are low in their sodium content, the cheese quality itself may be compromised because salt exerts a great influence on cheese quality as it affects the aspects of composition and controls the growth of undesirable microflora and enzymatic activity. Salting facilitates the control of microbial growth and activity, providing a selection of microbiota in the cheese $\mathrm{e}^{(4)}$. Thus one can observe, in low salt-containing cheeses, some sensorial defects, such as the lack of taste or a bitter taste, undesirable texture, and reduced control over the water activity, proteolysis and microbial growth ${ }^{(29)}$.

The Artisanal cheeses also exhibited wide variations in the sodium concentrations quantified among the commercialized brands (Figure 4). These differences registered up $68.64 \%$ between the $\mathrm{J}$ and $\mathrm{K}$ brands. This is clearly indicative of the lack of standardization of the added salt effected by the informal processing of this dairy product. The variations in the sodium levels shown in Figure 4 demonstrate the possibility of decreasing it, apart from implementing certain specific standardization for its addition during the preparation process, as excess consumption of salt can result several health hazards.

According to ANVISA Resolution No. 24 of 2010, "Food with a high amount of sodium is that which has in its composition an amount equal to or greater than $400 \mathrm{mg}$ of sodium per $100 \mathrm{~g}$ or $100 \mathrm{~mL}$ in the form in which it is exposed for sale." ${ }^{(30)}$. In light of this statement, $66.7 \%$ of the brands analyzed are high in sodium concentration, barring the $\mathrm{D}, \mathrm{G}, \mathrm{K}$ and $\mathrm{L}$ brands (Tables 1 and 2).

From the research done, Brazilians consume, on average, sodium in amounts that exceed by more than two times the maximum recommended consumption level by WHO, and the industrialized foods contributed a substantial quantity of that. Considering the escalating popularity of this food category in the normal diet of the Brazilian populace, the need to cut-down on the sodium concentration in foods is very pressing ${ }^{(24)}$. High blood pressure is closely linked to high sodium consumption, which causes increased risk for heart disease, 
stroke, congestive heart failure and kidney disease ${ }^{(31)}$. In Brazil, the leading causes of death in men and women were cardiovascular diseases ${ }^{(32)}$, and in 2013 they accounted for $31.0 \%$ of all deaths across the globe ${ }^{(33)}$.

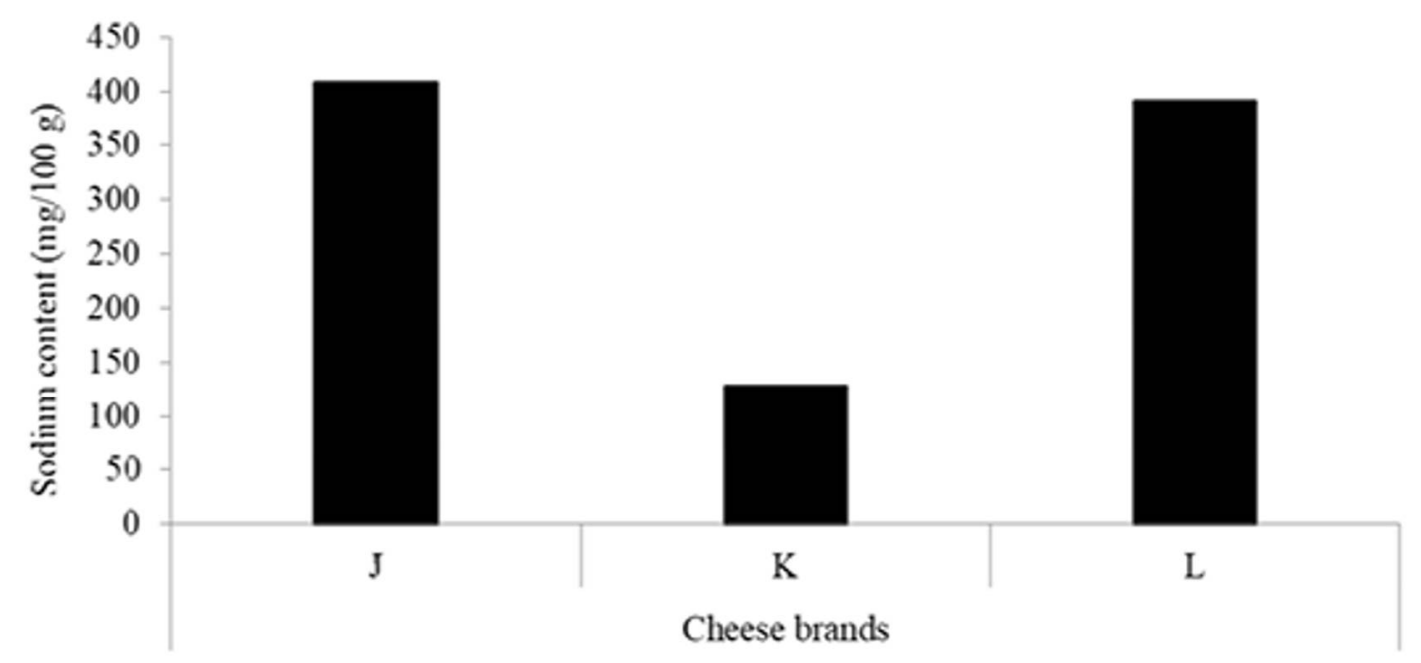

Figure 4. Difference in the sodium content among brands of Artisanal cheeses marketed in the western border of the Rio Grande do Sul.

The United States, in 2005, registered 395 thousand deaths due to hypertension ${ }^{(34)}$, while in 2009 , the medical expenses incurred to treat hypertension was a staggering US $\$ 73.4$ billion $^{(31)}$. From studies in the Netherlands, it is clear that in most food categories the $\mathrm{NaCl}$ levels in processed foods can be decreased by $50.0 \%{ }^{(35)}$.

At present, the daily sodium intake by the Brazilian population is around 4,700 $\mathrm{mg}$, equivalent to roughly 12 $\mathrm{g}$ of salt, compared to the WHO recommendation of a maximum of 2,000 mg/day or $5 \mathrm{~g}$ of salt. Should these levels be met, Brazil can decrease stroke deaths by $15.0 \%$, myocardial infarction by $10.0 \%$ and 1.5 million people would not require the support of arterial hypertension medication, according to data provided by the Ministry of $\mathrm{Health}^{(7)}$.

\section{Conclusion}

The sodium concentration determined in the cheeses revealed that the brands analyzed did not standardized quantity of the ingredients added in the formulation of products, because significant discrepancies were evident between the lots of the same brand and among the brands of the cheeses assessed. Besides, $44.4 \%$ of the companies showed noncompliance with the RDC 360/2003, which specifies mandatory nutrition labeling, because the sodium level identified exceeded the maximum permissible tolerance level set by the Brazilian legislation, showing complete disregard to consumer defense code. This study emphasizes that $77.8 \%$ of the cheese brands evaluated failed to meet the goal for sodium reduction that had been jointly set by the Ministry of Health and the Brazilian Association of Food Industries. Based on the ANVISA Resolution No. 24 of 2010, a significant percentage of $66.7 \%$ of the cheese brands analyzed were regarded as sodium-rich food.

The Artisanal cheeses showed lower sodium concentrations. However, as salt is of great technological advantage, particularly in inhibiting the microorganisms, these low sodium levels can compromise the quality of the cheeses.

Parmesan type cheese was demonstrated to have the highest level of excess sodium in its formulation (2014.56 
$\mathrm{mg} / 100 \mathrm{~g}$ ) among all the cheeses tested. Besides, it is alarming to note that this concentration has been rising over the years. This indicates the degree of neglect the industry has indulged in, with reference to consumer safety and the ill-effects of excess sodium consumption on their health.

Therefore, from this study the evident need is to create legislation to standardize and set limits on the companies for the amount of added sodium during the elaboration of cheeses. They also need to include sodium limits in the patterns of identity and quality of the cheeses, besides conducting regular inspections by competent agencies to supervise the food industry with regards to the accuracy of the information declared on the labels. In this context, when strong commitment is present to reduce the added sodium at all levels, the number of deaths from non-communicable chronic diseases can be minimized and the resources now being incurred to treat those diseases can be diverted and allocated to other sectors in Brazil.

\section{References}

1. Siqueira KB, Carneiro AV, Almeida MF, Souza RCN. O mercado lácteo brasileiro no contexto mundial. Circular Técnica 104 [Internet]. Juiz de Fora: Embrapa Gado de Leite; 2010 Dec [cited 2018 Jul 10]. Available from: https://ainfo.cnptia.embrapa.br/digital/bitstream/item/32886/1/CT104-Kennya.pdf. Portuguese.

2. Instituto Brasileiro de Geografia e Estatística. Produção da pecuária municipal [Internet] Rio de Janeiro: IBGE; 2015 [cited 2018 Jul 14]. Available from: https://biblioteca.ibge.gov.br/visualizacao/periodicos/84/ppm_2015 v43 br.pdf. Portuguese.

3. Associação Brasileira das Indústrias de Queijo. Imprensa [internet] 2014 [cited 2018 Jun 09]. Available from: http://www.abiq.com.br/imprensa/namidia/Valor\%20Economico $\% 20-\% 20$ Fabio $\% 20$ Scarcelli\%20$\% 20$ Mercado $\% 20$ de $\% 20$ queijos $\% 20$ cresce $\% 20$ no $\% 20$ pa $\%$ C3\%ADs $\% 20 \mathrm{e} \% 20$ atrai $\% 20$ estrangeiros.pdf.

Portuguese.

4. De Paula JCJ, Carvalho AF, Furtado MM. Princípios básicos de fabricação de queijo: do histórico à salga [Basic principles of cheese production: from historical to salting]. Revista do Instituto de Laticínios Cândido Tostes [Internet]. 2009 [cited 2018 Sept 10]; 64(367):19-25. Available from: https://www.revistadoilct.com.br/rilct/article/view/76/82. Portuguese.

5. Buzzo ML, Carvalho MFH, Arakaki EEK, Matsuzaki R, Granato D, Kira CS. Elevados teores de sódio em alimentos industrializados consumidos pela população brasileira [High sodium contents in processed foods consumed by Brazilian population]. Revista do Instituto Adolfo Lutz [Internet]. 2015 [cited 2018 Jul 11]; 73(1):32-39. Available from: http://www.ial.sp.gov.br/resources/insituto-adolfolutz/publicacoes/rial/rial73_1_completa/artigos-separados/1587.pdf. Portuguese.

6. Instituto Brasileiro de Geografia e Estatística. Pesquisa nacional de saúde 2013. Percepção do estado de saúde, estilos de vida e doenças crônicas [internet] Rio de janeiro: 2014 [cited 2018 Sept 14]. Available from: https://biblioteca.ibge.gov.br/visualizacao/livros/liv91110.pdf. Portuguese.

7. Cardin I. Acordo Eficaz. Revista Nacional da Carne [Internet]. 2014 [cited 2018 Jul 11]; 54(446):20-28. Available from: https://issuu.com/btsinforma/docs/revista_nacional_da_carne_ed_446. Portuguese.

8. Brasil. Ministério da Saúde. Extrato de Compromisso. Termo de compromisso que firmam entre si a União, por intermédio do Ministério da Saúde, a Associação Brasileira das Indústrias da Alimentação - ABIA, a Associação Brasileira das Indústrias de Queijos - ABIQ, a Associação Brasileira da Indústria Produtora e Exportadora de Carne Suína - ABIPECS, Sindicato da Indústria de Carnes e Derivados no Estado de São Paulo - SINDCARNES e União Brasileira de Avicultura - UBABEF. Diário Oficial da União. 2013 Dec 13. nº 242. Seção 3. P. 160. Portuguese. 
9. Associação Brasileira das Indústrias da Alimentação. Notícias [internet] 2017. [cited 2018 Sept 02]. Available from: https://www.abia.org.br/vsn/tmp_2.aspx?id=341. Portuguese.

10. Brasil. Ministério da Agricultura, Pecuária e Abastecimento. Manual de métodos oficiais para análise de alimentos de origem. Secretaria de Defesa Agropecuária. [internet] 2018. [cited 2018 Apr 02]. Available from: http://www.agricultura.gov.br/assuntos/laboratorios/legislacoes-emetodos/poa/copy3 of Manualdemtodosoficiaisparaanlisedealimentosdeorigemanimalled.rev_pdf. Portuguese.

11. Triola MF. Introdução à estatística. 10 th ed. Rio de Janeiro: Ltc; 2008. 868p. Portuguese.

12. Míkva M, Prajová V, Yakimovich B, Korshunov A, Tyurin I. Standardization-one of the tools of continuous improvement. Procedia Engineering [Internet]. 2016 [cited 2018 Jul 02]; 149:329-332. Available from: https://www.sciencedirect.com/science/article/pii/S1877705816311845. English.

13. Brasil. Ministério da Saúde. Agência Nacional de Vigilância Sanitária. Resolução da Diretoria Colegiada no. 360 de 23 de dezembro de 2003. Regulamento Técnico Sobre Rotulagem Nutricional de Alimentos. Diário Oficial da União. 2003 dez 26. Seção 1. Portuguese.

14. Karam LB, Nunes TK, Paiva RDL, Biasi RS, Gomes C, Galeb LDAG, et al. Avaliação da informação nutricional de marcas comerciais de requeijão cremoso [Evaluation of nutritional information of commercial brands of requeijão]. Revista Acadêmica Ciência Agrária Ambiental [Internet]. 2012 [cited 2018 Jun 02]; 10(3): 293-301. Available from: https:/periodicos.pucpr.br/index.php/cienciaanimal/article/viewFile/12275/11609. Portuguese.

15. Silva LFM, Ferreira KS. Avaliação de rotulagem nutricional, composição química e valor energético de queijo minas frescal, queijo minas frescal "light” e ricota. Alimentos e Nutrição. 2010 21(3):437-442.

16. Brasil. Lei $\mathrm{n}^{\circ}$ 6437, de 20 de agosto de 1977. Dispõe sobre infrações à legislação sanitária federal, estabelece as sanções respectivas, e dá outras providências. Diário Oficial da União. 1977 ago 24; p.11145. Portuguese.

17. Câmara MCC, Marinho CLC, Guilam MC, Braga AMCB. A produção acadêmica sobre a rotulagem de alimentos no Brasil. Revista Panam Salud Publica [Internet]. 2008 [cited 2018 Jul 11]; 23(1):52-58. Available from:

https://www.scielosp.org/article/ssm/content/raw/?resource ssm path=/media/assets/rpsp/v23n1/a07v23n1.p df. Portuguese.

18. Santos LAS. Educação alimentar e nutricional no contexto da promoção de práticas alimentares saudáveis [Food and nutrition education in the context of promoting healthy food practices]. Revista de Nutrição [Internet]. 2005 [cited 2018 Jul 10]; 18(5):681-692. Available from: http://www.scielo.br/pdf/rn/v18n5/a11v18n5.pdf. Portuguese.

19. Lobanco CM, Vedovato GM, Cano CB, Bastos DHM. Fidedignidade de rótulos de alimentos comercializados no município de São Paulo, SP [Reliability of food labels from products marketed in the city of São Paulo, Southeastern Brazil]. Revista de Saúde Pública [Internet]. 2009 [cited 2018 Jul 10]; 43(3):499505. Available from: http://www.scielo.br/pdf/rsp/2009nahead/316.pdf. Portuguese.

20. Brasil. Lei n. 8078, de 11 de setembro de 1990. Dispõe sobre proteção do consumidor, e dá outras providências. Diário Oficial da União. 1990 set 12. Seção 1, p.1. Portuguese.

21. Brasil. Ministério da Saúde. Agência Nacional de Vigilância Sanitária. Informe Técnico n. 69/2015. Teor de sódios em alimentos processados [Internet]. 2015. [cited 2018 Aug 15] Available from: http://portal.anvisa.gov.br/documents/33916/388729/Informe+T\%C3\%A 9cnico+n $\% \mathrm{C} 2 \% \mathrm{BA}+69+\mathrm{de}+2015 / 8$ 5d1d8f0-5761-4195-9aee-e992abd29b3e. Portuguese. 
22. Bemfeito RM, Rodrigues JF, Silva JGE, Abreu LR. Temporal dominance of sensations sensory profile and drivers of liking of artisanal Minas cheese produced in the region of Serra da Canastra, Brazil. [Internet]. J Dairy Sci. 2016. [cited 2018 Dez 22]; 99(10):1-12. Available from: https://www.journalofdairyscience.org/article/S0022-0302(16)30490-8/pdf. English.

23. Sobral D, Costa RGB, De Paula JCJ, Teodoro VAM, Moreira GMM, Pinto MS. Principais defeitos em queijo Minas artesanal: uma revisão [Major defects in artisanal Minas cheese: a review]. Revista do Instituto de Laticínios Cândido Tostes [Internet]. 2017 Apr/Jun [cited 2018 Dez 22]; 72(2):108-120. Available from: https://www.revistadoilct.com.br/rilct/article/view/600/437. Portuguese.

24. Instituto Brasileiro de Defesa do Consumidor. Redução de sódio em alimentos: uma análise dos acordos voluntários no brasil [internet] São Paulo: Caderno Idec, 2014. [cited 2018 Jun 14]. Available from: http://www.idec.org.br/uploads/publicacoes/publicacoes/caderno-idec-sodio-alimentos.pdf. Portuguese.

25. Dickel C, Junkes JK, Tonial IB, Castro-Cislaghi FP. Determinação do teor de sódio e lactose em queijos mussarela e colonial consumidos na região sudoeste do Paraná [Determination of sodium and lactose content in Mozzarella and Colonial cheese consumed in Southwestern Paraná]. Revista do Instituto de Laticínios Cândido Tostes [Internet]. 2016 [cited 2018 Jun 02]; 71(3):144-152. Available from: https://www.revistadoilct.com.br/rilct/article/view/528/411. Portuguese.

26. Brasil. Ministério da Saúde. Agência Nacional de Vigilância Sanitária. Rotulagem nutricional obrigatória. Manual de orientação às indústrias de Alimentos [Internet]. Brasília: 2005. [cited 2018 Jul 15]. Available from:

http://portal.anvisa.gov.br/documents/33916/389979/Rotulagem+Nutricional+Obrigat\%C3\%B3ria+Manual+ de+Orienta $\% \mathrm{C} 3 \% \mathrm{~A} 7 \% \mathrm{C} 3 \% \mathrm{~A} 3 \mathrm{o}+\% \mathrm{C} 3 \% \mathrm{~A} 0 \mathrm{~s}+\mathrm{Ind} \% \mathrm{C} 3 \% \mathrm{BAstrias}+\mathrm{de}+\mathrm{Alimentos} / \mathrm{ae} 72 \mathrm{~b} 30 \mathrm{a}-07 \mathrm{af}-42 \mathrm{e} 2-8 \mathrm{~b} 76-$ $10 \mathrm{ff} 96 \mathrm{~b} 64 \mathrm{ca} 4$. Portuguese.

27. Lima JLS, Montalvão, PNA, Pereira Neta IB, Maciel AR, Seixas VNC. Perfil do consumidor e determinação de Cloreto de Sódio em queijo artesanal [Consumer profile and determination of Sodium Chloride in artisanal cheese]. Revista Ciência e Tecnologia [internet]. 2017. [cited 2019 Jan 01]; 20(36):3544. Available from: http://www.revista.unisal.br/sj/index.php/123/article/view/524. Portuguese

28. Serviço Brasileiro de Apoio às Micro e Pequenas Empresas. Queijos nacionais: estudos de mercado [Internet]. 2008 Sept. [cited 2018 Aug 14]. Available from: http://www.bibliotecas.sebrae.com.br/chronus/ARQUIVOS_CHRONUS/bds/bds.nsf/4416AA3881FA433B8 32574DC00471EF1/\$File/NT0003909A.pdf. Portuguese.

29. Guinee TP, Sutherland BJ. Cheese: Salting of Cheese. In: Fuquay, JW. Encyclopedia of Dairy Sciences. 2nd ed. Cambrigde: Academic Press; 2011. P. 595-606. English.

30. Brasil. Ministério da Saúde. Agência Nacional de Vigilância Sanitária. Resolução da Diretoria Colegiada no. 24 de 15 de junho de 2010. Dispõe sobre a oferta, propaganda, publicidade, informação e outras práticas correlatas cujo objetivo seja a divulgação e a promoção comercial de alimentos considerados com quantidades elevadas de açúcar, de gordura saturada, de gordura trans, de sódio, e de bebidas com baixo teor nutricional. Diário Oficial da União. 2010 Jun 29; n 122, seção 1, p. 46. Portuguese.

31. Institute of Medicine. Strategies to Reduce Sodium Intake in the United States [Internet]. Washington: Institute of Medicine; 2010. [cited 2018 Jul 06] Available from: https://www.ncbi.nlm.nih.gov/books/NBK50956/pdf/Bookshelf_NBK50956.pdf. English.

32. Mansur AP, Favarato D. Mortalidade por doenças cardiovasculares no Brasil e na região metropolitana de São Paulo: Atualização 2011 [Mortality due to cardiovascular diseases in Brazil and in the metropolitan region of São Paulo: A 2011 Update]. Arquivo Brasileiro de Cardiologia [Internet]. 2012 [cited 2018 Jul 10]; 99(2):755-761. Available from: http://www.scielo.br/pdf/abc/v99n2/aop05812.pdf. Portuguese. 
33. Benjamin EJ, Blaha MJ, Chiuve SE, Cushman M, Das SR, Deo R, et al. Heart Disease and Stroke Statistics 2017 At-a-Glance [Internet] American Heart Association; 2017. [cited 2018 Sept 10]. Available from: https://healthmetrics.heart.org/wp-content/uploads/2017/06/Heart-Disease-and-Stroke-Statistics-2017ucm 491265.pdf. English.

34. Danaei G, Ding EL, Mozaffarian D, Taylor B, Rehm J, Murray CJL, et al. The Preventable Causes of Death in the United States: Comparative Risk Assessment of Dietary, Lifestyle, and Metabolic Risk Factors. PLoS Med [Internet]. 2009 Apr [cited 2018 Sept 10] 6(4): e1000058. Available from: https://www.ncbi.nlm.nih.gov/pmc/articles/PMC2667673/pdf/pmed.1000058.pdf. English.

35. Hendriksen MAH, Verkaik-Kloosterman J, Noort MW, van Raaij JMA. Nutritional impact sodium reduction strategies on sodium intake from processed foods. European Journal of Clinical Nutrition [Internet]. 2015 [cited 2018 Sept 04]; 69(7):805-810. Available from: https://www.ncbi.nlm.nih.gov/pmc/articles/PMC4493647/pdf/ejen201515a.pdf. English. 